\title{
THE SURVEILLANCE AND PERSECUTION OF SLOVENE ANTIFASCISTS IN ARGENTINA: HOW THE AUTHORITIES CONSPIRED IN COMBATING “UNDESIRED” IMMIGRATION
}

\author{
Miha ZOBEC
}

COBISS 1.01

\begin{abstract}
The Surveillance and Persecution of Slovene Antifascists in Argentina: How the Authorities Conspired in Combating "Undesired" Immigration
\end{abstract}

Opposition to the fascist policy in the Julian March, as well as to fascism in general, led to close surveillance of Slovene emigrants from this area by Fascist Italy. The author first provides an outline of the Italian surveillance of the activities promoted by emigrant associations, then analyses the pressure exerted by the Argentine authorities on leftist emigrants and the sharing of their criminal records with Italy, and finally focuses on antifascist activities promoted by female immigrants. He argues that the Italian extraterritorial surveillance depended on the type of emigrant transnational political engagement, which was motivated by increased suppression of the minorities in the Julian March.

KEY WORDS: fascist surveillance, emigrants from the Julian March, antifascism, emigrant political engagement, extraterritorial control of emigrants

\section{IZVLEČEK}

Nadzor in preganjanje slovenskih antifašistov v Argentini: Zarotniško delovanje oblasti pri spopadanju z »nezaželenimi« priseljenci

Zaradi nasprotovanja fašistični politiki v Julijski krajini, pa tudi fašizmu nasploh, je fašistična Italija skrbno nadzorovala slovenske izseljence iz Julijske krajine v tujini. Avtor v prispevku najprej prikaže italijanski nadzor nad dejavnostmi emigrantskih društev v Argentini, sledi analiza argentinskega pritiska nad levičarskimi izseljenci in izročanje njihovih dosjejev Italiji, na koncu pa pozornost posveti antifašistični dejavnosti izseljenk. Avtor ugotavlja, da je bil italijanski zunajteritorialni nadzor odvisen od transnacionalnega angažmaja izseljencev, ki se je povečal v času intenzivnega zatiranja manjšine v Julijski krajini.

KLJUČNE BESEDE: fašistični nadzor, izseljenci iz Julijske krajine, antifašizem, angažirani izseljenci, zunajteritorialni nadzor nad izseljenci

PhD in History, Assistant, University of Maribor, Faculty of Arts, Koroška c. 160, SI-2000 Maribor; miha.zobec1@gmail.com 


\section{INTRODUCTION}

Just a couple of months after settling in Argentina, Viktor Bogatec took part in a demonstration celebrating 1 May in Buenos Aires. The grandeur of the event was so impressive that he felt as if he were in paradise. Only eight days after his arrival he had joined the ranks of the communists. ${ }^{1}$ At that time, Franc Štoka, a fellow countryman from a neighbouring village and an ardent communist, had been waiting for him to disembark at the port in Buenos Aires. Štoka, known among his comrades as a brilliant orator, came to Argentina as a stowaway from the port of Antwerp. His zealous support of communist ideas made his life in the fascist Julian March ${ }^{2}$ difficult. In order to avoid the fascist justice system, he tried to escape prosecution by fleeing first to Yugoslavia and then to Germany. In Hamburg, he wanted to make a transoceanic voyage, but the Italian consulate rejected his request for the documents needed to cross the Atlantic. Nevertheless, he was not dissuaded from his plan and embarked on a ship in Antwerp without the necessary papers. Upon arriving in Argentina he quickly joined the communist party and soon became one of the most strident members of its Yugoslav section. As a persuasive speaker, he posed a considerable threat to the established political order. After the coup that established a military dictatorship in 1930 he was constantly harassed by the authorities until he was finally expelled from the country in 1933.

The Italian authorities were familiar with Štoka's revolutionary activities even before his repatriation and ensuing confinement on the island of Ponza. In fact, the endeavours of the Argentine police to suppress the leftist immigrants from the Julian March appeared to be closely monitored by the Italian diplomatic service. The fascist system of the surveillance of "subversives", conducted by the staff of the Casellario Politico Centrale (Central Political Repository, hereinafter CPC) was not entirely new. Initially a list of subversives drawn up before the end of nineteenth century to quell labour unrest, in 1926 the CPC became an autonomous office, reporting directly to the Division for Public Safety of the Ministry of the Interior. Suppression of the antifascist movement became the primary goal of this division and the list of people who were under observation was greatly expanded (Cresciani 2004: 8; Tosatti 1992: 134; Serio 1985: 75). Although the fascist system of surveillance appeared to be a continuation of the one used in Liberal Italy, the fascist pursuit of controlling all the spheres of society was in fact unprecedented (Dunnage 2008: 246). The reorganization of the police undertaken by the new police chief in 1926 along with the adoption of the

1 Department of History and Ethnography at the Slovene National and Study Library in Trieste (OZE NŠKT), Emigration Collection, Interview by Aleksej Kalc with Viktor Bogatec, 21 March 1988; Štoka's story is based on the documents in his personal file from the Archivio Centrale dello Stato (ACS), Casellario Politico Centrale (CPC), box (b.) 4958, file (f.) 012685.

2 The 'Julian March' is the English translation of the Slavic designation (Julijska krajina) for the Venezia Giulia region, which was annexed to Italy in November 1920. It referred to the territory including Trieste, Gorizia, Istria and parts of the Dalmatian coast (Hametz 2005: 87). 
leggi fascistissime (thoroughly fascist laws) in the same year institutionalized surveillance and introduced unparalleled levels of social control. The system, founded on the act of gathering data on the regime's opponents, turned Italy into a "dossier society" where police files were kept on anybody posing a threat to the regime (Fonio 2011: 81). The lack of archival research on the subject, however, makes it difficult to identify any differences that might have appeared in the system between the centre and the peripheries. However, it could be said that the main distinction was that the fascist regime treated the Slavic minorities of the Julian March as racially inferior and subjugated them by the use of the stick without the carrot (Kacin Wohinz 2008: 72; Verginella 2016: 715). In contrast, consent in central Italy was achieved through a combination of coercion and seduction (Ghirardo 1996: 365). These facts indicate that the surveillance conducted by the fascismo di confine (border fascists) in the Julian March was more pervasive than that in central Italy from the very beginning. ${ }^{3}$

Fascist policy regarded emigration as a vehicle for expanding Italian hegemony. In order to accomplish this, the fascists worked to transform the Italian emigrants into colonies within the fascist empire (Gabaccia 2000: 130). Moreover, fascist diplomatic policy equated fascism with Italian identity, and considered any opposition to the regime to be anti-Italian (Pretelli 2010: 60-61). Not only were antifascists closely monitored, anybody who did not adhere to the fascist propaganda abroad raised considerable suspicion (Franzinelli 1999: 170). The associations of emigrants from the Julian March which exposed the discrimination against the minorities in that region were by definition anti-Italian, and the fascist diplomatic service did not hesitate to monitor their activities. I will use documents from the Italian embassy in Argentina to demonstrate how Italy increased its extraterritorial control over the emigrants from the Julian March at the time when the antifascist resistance in the Julian March was at its peak. While the files of the CPC enable us to analyse the state's surveillance system, they also allow us to take a closer look at the individuals who were under observation (Dilemmi 2010: 1-2). Consequently, in the following section I examine the surveillance of the politically active emigrants involved in the Argentine labour movement and show how the Argentine authorities suppressed them and reported their activities to Italy. In order to present their personal backgrounds, I supplement the materials from the Italian authorities with interviews and memoirs. My next objective is to show that the level of surveillance did not necessarily depend on the level of personal engagement. I will demonstrate that certain individuals who were not committed to political ideals were nevertheless under observation. Conversely, many fervent activists were given files only when police pressure in Argentina increased. Finally, l examine the activity of women.

The relentless surveillance of emigrants from the Julian March was an extension of the fascist policy of national expulsion at home. The Italian nationalizing migration

3 Fonio divides the fascist surveillance into two phases. In the first phase the antifascists were under surveillance, while the second (which coincided with the anti-Semitic turn in the second half of the 1930s) included all ranks of society (Fonio 2011). 
policy exacerbated interwar European trends aimed at purifying the nation by encouraging the departure of ethnic minorities, while restricting the exit of people belonging to the dominant ethnic group (Zahra 2016: 109-110; Brunnbauer 2012: 605). Thus the migration of Slovenes and Croats from the Julian March is not surprising. It reached its peak after the strategy of prohibition of emigration of ethnic Italians was adopted in 1927. This new demographic policy coincided with increased discrimination against the Slavic population from the Julian March and served as a pretext for encouraging their departure (Kalc 1996: 25-27; Kacin-Wohinz 1990: 24-27). The atmosphere of intimidation and fear, so ubiquitous in fascist Italy, was further aggravated in the Julian March by policies of forced assimilation directed against the "allogenic" population (the official fascist policy declared Slovenes and Croats to be foreigners on their own soil) (Ebner 2011: 14). Although individual motivations for migration varied from political exile to economic deprivation, it was the general feeling of precariousness that led people to emigrate (Kalc 1996: 25).

The country which received the greatest share of immigrants was neighbouring Yugoslavia, regarded by many Slovenes and Croats as their home. Associational activities, dismantled by the fascist rule in the Julian March, could in many ways continue functioning unhampered there. Argentina, on the other hand, accepted around 22,000 Slovene immigrants and became the most important overseas destination (Sjekloča 2004: 79). It also welcomed communists, who were being persecuted in Yugoslavia. The pull factor attracting immigrants to Argentina was significant and coincided with the major push factor driving the "allogenic" population out of Italy. Furthermore, the natural growth of the Argentine population was not high enough to meet the needs of its expanding economy. Therefore, immigration was an obvious solution to facilitate further industrial growth. Many Slovene emigrants found jobs in the flourishing urban construction sector (Lewis 1992: 187-189; Mislej 1996: 95).

However, after the putsch by General Uriburu in 1930 and the ensuing undemocratic government, associations of emigrants from the Julian March were subject to police raids, and many dedicated members, particularly those active in the Argentine labour movement, were imprisoned. The Argentine repression was supported by diplomatic representatives from Italy and Yugoslavia, as well as by denunciation at the hands of Slovene emigrants themselves. ${ }^{4}$ Although emigrants from the Julian March were not legally bound to Yugoslavia, its authorities advanced jurisdictional claims over them due to the image of the Yugoslav state as representing the emigrants' true national homeland (Kurinčič 1981: 175; Rahten 2009: 82). ${ }^{5}$ The Yugoslav aspect would certainly be worth examining, especially in the light of the rapprochement between Yugoslavia and Italy in the second half of the 1930s. However, in this paper I will focus

4 The Slovene communists were complaining that members of the national-liberal group were denouncing them to the police. Cf. »Slovenski fašisti na delu«, Borba, April 1931, p. 3.

5 The editor of the nationalist group's newspaper was also a victim of Yugoslav denunciations (see Kacin 1937). 
on the Italian concerns over antifascist activism and the Italian cooperation with the Argentine authorities, starting with the surveillance of associations.

\section{SURVEILLANCE OF IMMIGRANT ASSOCIATIONS}

The association activities of the emigrants from the Julian March in Argentina drew on the system that had been dismantled by the fascist authorities at home. Antifascism united the emigrants (Kalc 2016), although the way in which the antifascist struggle was perceived varied significantly. While emigrants with a Liberal Catholic political background viewed the fascist pillage in the Julian March through a nationalist perspective, bemoaning the enslavement of their "brothers" at home, ${ }^{6}$ the communists believed that fascism was the product of global capitalist domination which had to be opposed through an international proletarian revolt.

Political divisions were the source of infinite disputes among emigrants, and they markedly influenced the way associations were subjected to surveillance. Although the fascist diplomatic corps considered both groups to be a threat to Italian power, the Argentine authorities were only concerned about the communists, whose activities were subsequently denounced to Italy. It should be noted that the Italian extraterritorial control over the emigrant activities was spurred by emigrant transnational political engagement in the form of long-distance nationalism (nationalism crossing borders, or in this case, continents) (Skrbiš 1999: 6), which was, in turn, motivated by the repression of the minorities in the Julian March (cf. Brunnbauer 2009). Local institutions such as the prefectures in the emigrants' places of origin played a crucial role in the fascist extraterritorial control. Information concerning suspicious emigrants was passed from both the consular officials to the CPC and then to the prefectures, as well as the other way around. However, it appears that the prefectures were asking the embassy in Buenos Aires to provide information regarding the emigrants' political engagement during the time of intense antifascist activism in the Julian March $^{7}$ (cf. Franzina 1983: 826).

In contrast to the control exercised over the liberal group, the surveillance of the communists seemed to be constant and relatively independent of the situation in the Julian March. The most fervent leftist activists had already been under surveillance even before emigrating overseas, while others were given files later due to their engagement in the Argentine labour movement. In fact, those who already had a file before departing were continuously monitored after settling in Argentina. Consular officials could penetrate emigrant communities thanks to the support of the OVRA (Organization for Vigilance and Suppression of Anti-Fascism), the fascist

6 »Obletnica suženjstva našega Primorja« [Anniversary of the Enslavement of our Primorje Region], Slovenski tednik, 9 November 1929, p. 1.

7 Archive of Slovenia (AS), 1829/362, technical unit (t. u.) 15, Message of Italian embassy in Argentina to Prefecture of Gorizia and CPC, 10 Aug 1931. 
secret service. The OVRA agent was undoubtedly familiar with the emigrants' backgrounds as he had spent three years in Ljubljana before coming to the Argentine capital (Franzinelli 1999: 172).

The embassy labelled the emigrants' challenge to Italian rule over the Julian March as anti-Italian and showed particular interest in the money that the emigrants were sending home. ${ }^{8}$ Fundraising and other forms of transnational engagement of emigrants in helping those oppressed in the Julian March intensified after the fascists managed to subdue the antifascist resistance in the region. By 1931, when the Italian embassy was answering the messages coming "daily from local administrative bodies and the CPC", surveillance seemed to be well underway. We can assume that Italian control over Slovene emigrants was spurred by the protests against the Italian show trials in the Julian March. The first of these trials was staged in Pula, where a special fascist tribunal for the defence of the state was formed in order to condemn the antifascist activism of the "allogenes" in Istria. Two other trials following a similar pattern were subsequently held in Trieste, the first in 1930 and the second in 1941. Vladimir Gortan, a member of the underground antifascist organisation TIGR, who allegedly shot one of the voters during the fascist elections in Pula, was tried and executed for "assassinating the fascist regime and the order of the Italian state" (Kacin Wohinz 2008: 128). The death sentence carried out in Pula in 1929 led to large public demonstrations organized by emigrants from the Julian March. The members of the Slovene liberal group Prosveta wrote a letter of protest together with Croats and Serbs, demanding democracy and the end of fascist terror in the Julian March. This letter, later sent to the League of Nations, was read out at a large public meeting proclaiming Gortan a "national martyr".

A separate meeting crossing national boundaries was held by people with a labour background. Giuseppe Tuntar, who delivered a speech at this meeting, was known among emigrants from the Julian March as a communist deputy who had vigorously denounced the fascist discrimination of minorities in the Julian March in the Italian parliament (Patat 1989). His arrival in Argentina in 1924 strengthened both the Italian and Yugoslav sections of the communist party. He was constantly under the surveillance of Italian officials, who portrayed him as one of the most "hot-headed communists living in Buenos Aires" who made "venomous speeches against Italy" at "various antifascist public meetings"10 (Luiàn Leiva 1983: 559-560). A protest in condemnation of Gortan's execution was organised by the Slovene socialist association

8 AS 1829/362, t.u. 15.

9 »Poročilo iz nedeljskega protestnega shoda proti fašizmu radi ustrelitve Vladimirja Gortana in obsodbe njegovih tovarišev«, Slovenski tednik, 2 November 1929, p. 1. ACS, CPC, b. 5240, f. 026121, Giuseppe Tuntar. 
Ljudski oder ${ }^{11}$ and the Italian antifascist emigrant society Circolo Venezia Giulia, which had been co-founded by Tuntar. The Italian political police, which monitored the meeting, expressed concerns about the "violent" antifascist speeches delivered by Tuntar and the president of Ljudski oder, Franc Štekar. ${ }^{12}$

Subsequently, the members of Ljudski oder participated in a protest organized by Italian antifascists in condemnation of the show trial held in Trieste ${ }^{13}$ (Mislej 1996: 98). The trial, which involved the sentencing of those involved in a bomb attack on the fascist newspaper II popolo di Trieste in the Julian March, coincided with Uriburu's putsch on 6 September 1930 and was the subject of intense interest among emigrants from the Julian March around the world (Kalc, Milharčič Hladnik 2015). Unfortunately, not much is known about the reaction of emigrants in Argentina, since Uriburu introduced fascist-like rule characterized by the violent suppression and torture of political opponents (Finchelstein 2010: 74-75). The previously cited report, which the embassy issued in 1931, indicates that Italy was highly preoccupied with the intense antifascist activism of emigrants from the Julian March undertaken in response to the Trieste trial. Furthermore, the cooperation between the liberal emigrant group and the Zveza jugoslovanskih izseljencev iz Julijske krajine (The Union of Yugoslav emigrants from the Julian March), based in the Kingdom of Yugoslavia, with the aim of achieving eventual annexation of the contested region to Yugoslavia in the beginning of thirties, probably triggered additional surveillance of the liberal group (Kalc 2016). However, Italian control over these activities requires further analysis.

\section{SURVEILLANCE OF POLITICALLY ENGAGED COMMUNISTS}

Franc Štoka, a leader of the branch of Ljudski oder in the village of Kontovel/Contovello near Trieste, escaped from Italy after the issue of an arrest warrant in 1926. His name was added not only to the files of the CPC, but also to Bolletino delle ricerche, the fascist regime's list of most wanted persons ${ }^{14}$ (Serio 1985: 75). According to the CPC files, people under surveillance were classified into several categories, including communists, which was where Štoka was classified. These categories make the CPC files a useful tool for statistical analyses of antifascism. Of course, distortions are inevitable, since the information was inserted at the end of penal procedures. Što$\mathrm{ka}$, for instance, figures as someone who was active in Italy, although he had been

11 First a labour cultural organisation established in 1905 in Trieste, Ljudski oder [The People's Stage] embraced communism in 1921. After the First World War, the organization suffered a fascist backlash until it was finally outlawed in 1923. Just two years after the organization was banned in Italy, emigrants with a labour background established its successor in Argentina (Ščurk, Štoka 1973: 198-199).

12 ACS, CPC, b. 5240, f. 026121, Giuseppe Tuntar.

13 AS 1696, Franc Štoka, »Ob 37-letnici Ljudskega odra«.

14 ACS, CPC, b. 4958, f. 012685, Francesco Stoka. 
involved in activities in Argentina, and he only served prison sentences in Italy (cf. Dilemmi 2010: 3; Kalc).

Graph 1: Division of insurrectionaries from provinces of Trieste and Gorizia by place of residence

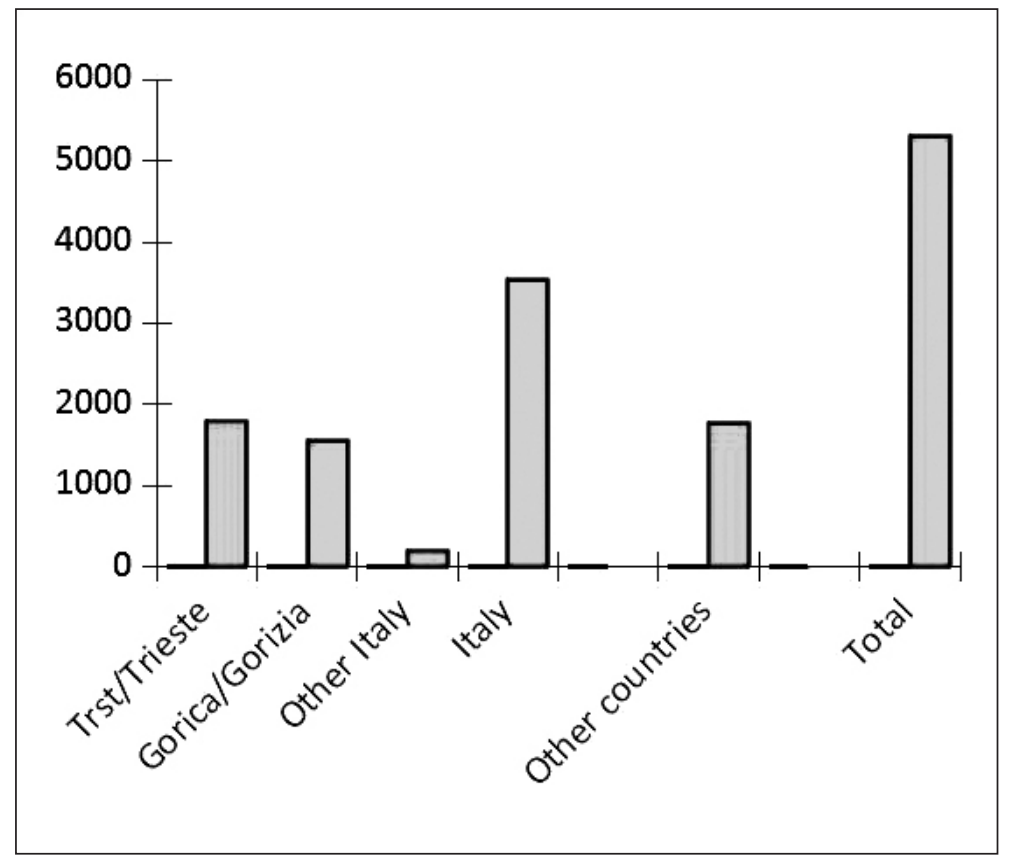

Sources: Statistic based on the CPC records by Aleksej Kalc

The Trieste trial also affected Štoka personally, since his brother Vladimir was sentenced to twenty years in prison for his alleged attack on the aforementioned fascist newspaper. The Italian authorities concluded that Štoka had a considerable influence on the Argentine proletariat (he also held important positions in Alleanza antifascista), so perhaps it is not surprising that an article condemning the fascist verdict appeared even in the labour newspaper El trabajo in Mar del Plata, the coastal town to which Štoka had moved probably in order to avoid persecution in the capital..$^{15}$

Štoka's arrival in Argentina in 1928 coincided with the massive influx of immigrants from the Julian March. Together with Leopold Caharija, who followed Štoka a year later, Albin Kralj (registered as Albino Carli by the Italian authorities) and a handful of other dedicated communists, he took over the leadership of Ljudski oder..$^{16}$ Upon arriving in Buenos Aires they tied Ljudski oder to the Argentine communist party, particularly to its Yugoslav section. They preferred to form alliances based on

15 Ibid.

16 OZE NŠKT, Izseljenstvo, Interviews by Kalc with Caharija and Sonja Kralj (Albin Kralj's daughter). 
class rather than nationality, and they initially saw the group of national-liberal Slovene immigrants as bourgeois fascist sympathizers. ${ }^{17}$

Although Slovene immigrants experienced economic prosperity upon their arrival in Argentina, labour rights were not guaranteed, and the trade unions depended on obrerismo, as Yrigoyen's ${ }^{18}$ paternalistic policy of informal cooperation with trade union leaders was called. Moreover, in the late 1920s, Argentina experienced significant labour unrest, with strikes eventually paralysing the whole country (Korzeniewicz 1993: 25-31; Horowitz 2008: 185-195). The Slovene immigrants were affected by intense labour confrontations, and the members of Ljudski oder considered participation in strikes in order to improve the life of immigrant workers to be just as important as the legal support offered by the mutual aid associations. Since the authorities did not approve of Ljudski oder's participation in the labour movement, the organization became the target of police persecution ${ }^{19}$ (Genorio 1987: 191).

Pressures by the political police were exacerbated after the putsch by General Uriburu and the subsequent Decada Infame, the "infamous decade" of electoral fraud and abuse of political power. The authoritarian governments incarcerated Štoka because of his agitation during strikes at the docks and dissemination of propaganda material for the celebrations of 1 May in the early 1930s. ${ }^{20}$ Štoka often worked at the port in Buenos Aires, the place which also witnessed the largest labour strikes. He was a longshoreman, although he dedicated his life to the communist cause and never had a stable job. ${ }^{21}$ Leopold Caharija, a carpenter equally devoted to communism, was imprisoned because he fired a weapon at the chief of the Argentine police at a meeting organized to legalize the communist party and in protest against Uriburu's military dictatorship. ${ }^{22}$ Oddly enough, even though Caharija spent almost a year in prison, his case was not reported to the Italian authorities. Although he had been active in the Julian March, it appears he was operating underground, and this is probably why the fascists could neither spot him nor add him to the CPC records. Nevertheless, the majority of the twenty members of Ljudski oder who were ardent communists did not have a police record before coming to Argentina. Moreover, even though Ljudski oder had been raided by the police and the association had been closed during the military dictatorship, the members' individual criminal records were not sent to Italy.

It was not until the restructuring of the police forces undertaken by president Justo that the criminal records of the Slovene leftists were forwarded to the Italian authorities. Instead of cutting back on the practice of political policing, the fraudulently

17 »Ust. obč. zbor nepolit. društva Prosveta«, Delavski list, July 1929, p. 3.

18 Hipolito Yrigoyen was the Argentine president between 1916-1922 and 1928-1930.

19 AS 1696, »Ob 37-letnici ..."

20 ACS, CPC, b. 4958, f. 012685, Francesco Stoka.

21 In the file of the CPC, his employment is described as "pescatore-muratore-stivatore" (fisherman, bricklayer, longshoreman) (ibid.).

22 OZE NŠKT, Izseljenstvo, »Dogodek iz leta 1930« - Leopold Caharija. 
elected Justo, who succeeded Uriburu in 1932, entrenched it even more deeply in the bureaucracy. Immigrants from the Julian March were persecuted by a special police unit in charge of combating communism, which managed to penetrate immigrant associations thanks to its team of translators from immigrant communities. Pre-emptive surveillance was increased during Justo's rule, and as soon as the special police unit noticed any suspicious activity they immediately informed the diplomatic representatives from the immigrants' countries of origin (Kalmanowiecki 2000: 42-46). Due to the intensification of political policing, along with the persistent economic crisis and the absence of new immigrants, Ljudski oder's labour engagement was curtailed. Even though the premises of the association reopened after the end of the military dictatorship, its activities were hampered by frequent police raids. The association came to an abrupt end in 1933 when the police raided a meeting of the association's general assembly and arrested many of its members. Most of the nearly fifty detainees were released after two weeks of imprisonment. Nevertheless, the Argentine police sent a list of prisoners to the Italian Ministry of the Interior and the latter subsequently reported them to the prefectures of Trieste/Trst, Pola/Pula, Fiume/Rijeka and Gorizia/Gorica. Furthermore, the ministry asked the local authorities to provide additional information on the arrested subjects. ${ }^{23}$

Many of those arrested were given CPC files, which meant that they were placed under constant surveillance and their files had to be updated regularly. Furthermore, their family members and relatives in Italy were put under the watchful eye of the Carabinieri or of the fascist paramilitary (Cresciani 2004: 11). The local authorities did not fail to obey the orders of the ministry concerning the Julian March communists who had been arrested in Argentina. Their families in the Julian March were subject to thorough inquiries. For instance, the family of Mirko Ličen, who was elected president of Ljudski oder at a prison assembly, was labelled as "apathetic and indifferent towards the regime". Even though, according to the Italian authorities, Ličen had shown only "Slavic feelings" prior to his departure, his brief imprisonment was enough for him to be closely monitored and an arrest warrant was issued by the chief of the local police in Gorizia. ${ }^{24}$ Štoka, on the other hand, faced a more severe punishment. During the Decada Infame, the Argentine authorities took advantage of a law that enabled arbitrary deportation in order to get rid of undesired immigrants. ${ }^{25}$ Štoka was among those who were deported and extradited to their countries of origin. He was followed a year later by Albin Kralj, while Leopold Caharija left Argentina voluntarily to fight in the Spanish Civil War.

23 AS 1696, Franc Štoka, »Občni zbor v zaporu«; AS 1829/362, t. u. 15.

24 ACS, CPC, b. 2784, Federico Licen.

25 The Argentine Congress passed a law called "Ley de residencia" (Law of residence) in 1902 in order to efficiently and quickly deal with the undesired activism of the growing labour movement. The law was derogated only in 1958 by president Frondizi (see Oved 1976). 


\section{SURVEILLANCE AND IMMIGRANTS' DIVERGENT LIFE-PATHS}

Ardent communists like Franc Štoka were not the only persons subjected to surveillance by the Italian authorities. Even individuals who were not engaged in an open antifascist struggle were often persecuted by the fascist system.

The control exercised by the fascist totalitarian regime was practically limitless. Even the ethnically Italian antifascist emigrants living in such a distant and for Italian diplomacy uninteresting country as Australia were subject to it (Cresciani 2002: 22). It is therefore not surprising that the surveillance of those who emigrated from the borderland region of the Julian March, which Italy strived to portray as a well-integrated part of its national territory, was so relentless and affected so many unengaged individuals.

By the examining files of those who were not fearless antifascists it is possible both to understand the extensive and deeply personal nature of the fascist repression and to analyse the emigrants' multifaceted biographies (cf. Ebner 2006: 215). An insight into the latter can highlight the contrasts between the fervent engagement of Štoka's comrades and the apathy shown by many members of $L j u d s k i$ oder. ${ }^{26}$ There were many who distanced themselves from immigrant associations and eventually joined them again. Leopold Ličen from Gorica/Gorizia (not a relative of Mirko Ličen) was arrested one year after his arrival in Argentina in 1930. Italian officials found out that he was a member of the Alleanza and registered him as comunista da segnalare (a communist whose activities had to be reported). Subsequently, his activism seemed to subside and in 1937 he was noted as a member of the Tabor association, a Slovene organization that supported the Yugoslav regime and was therefore in conflict with Ljudski oder. In 1940, he appeared again as a member of Ljudski oder, although his activities were supposedly negligible at that time. ${ }^{27}$

Certain individuals found themselves under surveillance only because they were friends with wanted communists. Viktor Bogatec, one of Štoka's companions, was arrested in February 1933 because he had been seen at the headquarters of various communist organizations. Even though his stable income as a tailor discouraged him from becoming as engaged as his comrades, his arrest and his friendship with Štoka sufficed to place him under surveillance by the CPC. By the time he returned to Trieste (due to his wife's homesickness they decided to repatriate), the Italian local police were well informed about his activities in Argentina and kept him under surveillance until the beginning of the Second World War. ${ }^{28}$ The cases of Ličen and Bogatec go to show that surveillance did not necessarily correspond to the level of political engagement of "subversive" individuals. Furthermore, the materials belonging to the CPC should be further analysed in order to examine both the nuances within

26 See the article »|z društvenega življenja« criticizing the indifference to the association. In: Spominu Ivana Cankarja: ob 25. letnici smrti, 1918-1943, p. 41.

27 ACS, CPC, b. 2784, Licen Leopoldo Corrado.

28 ACS, CPC, b. 692, Vittorio Bogatez. 
the seemingly monolithic immigrant groups and the scope of the fascist system of extraterritorial control.

\section{SURVEILLANCE OF WOMEN'S ANTIFASCIST ACTIVITIES IN ARGENTINA}

Women's names only seldom appeared in the CPC files. Even among the immigrants from the Julian March, the number of antifascist men greatly exceeded the number of their female counterparts (Graph 2).

Graph 2: Division of insurrectionaries from the Trieste and Gorizia provinces by gender

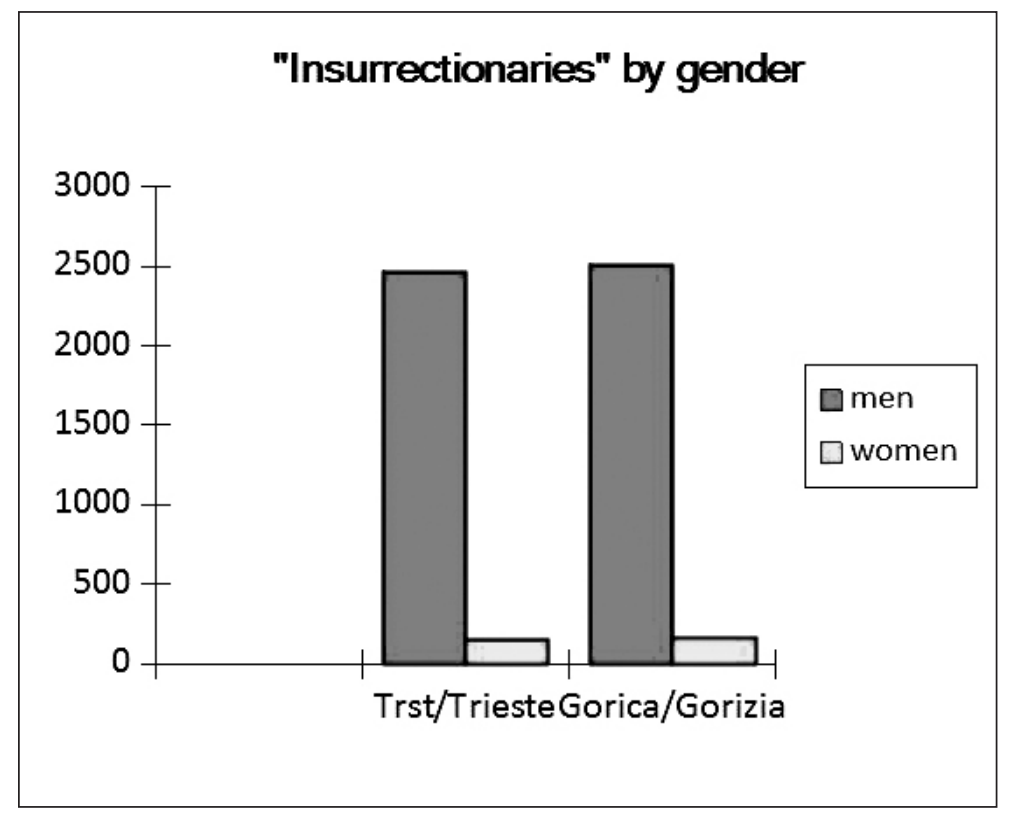

Sources: Statistic based on the CPC records by Aleksej Kalc

This fact, however, should not suggest that the role of women among Slovene antifascists from the Julian March was of secondary importance. On the contrary, the absence might imply that the engagement of women was tacit and unseen. Thus, in order to understand women's activism, the term antifascism should be broadened to include the existential aspect of opposing the imposed rule rather than just being a political category ascribed to those who openly engaged in fighting the regime (De Luna 1995: 11-12).

Although the majority of Slovene female immigrants were never given a CPC file, a handful of them were. Even though they had been given files before heading for Argentina, their activities abroad were closely monitored. Their case is particularly illustrative of the breadth of the fascist surveillance system. Josipina and Pavla Špacapan, 
apparently cousins from the villages of Ozeljan and Šempas respectively, were given files because they were found in a group of people singing songs celebrating Slavic power in Črniče, close to Ajdovščina. Although the Italian authorities labelled the songs as "anti-national" and categorized Josipina and Pavla as "Slavic irredentists", the two women were obviously not combating the regime by means of armed resistance. Nevertheless, the fascist authorities were determined to treat Josipina and Pavla as politically hostile. In the Julian March, where an especially harsh policy was imposed on ethnic minorities, the line between engaged antifascism and tacit opposition seemed to be particularly fragile, and even singing could be interpreted as a challenge to the fascist rule. Consequently, Italian diplomatic representatives monitored Josipina's and Pavla's activities in Argentina; they knew their home and workplace addresses and monitored their attendance at meetings of the Primorje association, whose members had been labelled "allogenic irredentists". They were placed under surveillance because they had broken the law at home, and although no request to report on their activities was issued, several reports regarding their life in Argentina were forwarded to the CPC up to $1941 .^{29}$

\section{CONCLUSION}

The extraterritorial control carried out by the Italian authorities was very often linked with the situation which the minority faced in the Julian March, as well as with the emigrants' transnational political engagement. The increased suppression of the minority triggered emigrant activism in the form of long-distance nationalism, which in turn paved the way to the escalation of extraterritorial surveillance. Italy was concerned with the emigrants' attempt to raise awareness of the repression of national minorities in the Julian March because the state propagated the belief that the "allogenic" population there had long since been assimilated (cf. Vinci 2011: 168).

Fascist extraterritorial control over the communists, on the other hand, appeared to be relatively constant and independent of what was happening in the Julian March. Nevertheless, the relentless surveillance of their political engagement demonstrates how Italy cooperated with the authorities of the host nation in subduing the emigrant activities. Argentina with its military dictatorship and the ensuing undemocratic governments was more than willing to crush the political activities of immigrants labelled as undesired and denounce them to Italy. Moreover, examining the files of the leftist activists allows us to understand both their transnational networks (they had significant connections with Slovene radical emigrants in France) and their alliances with leftist antifascists of other national origins in Argentina (cf. lacovetta, Ventresca 1996: 208). Considering the scarcity of the sources left by the emigrants themselves, a thorough scrutiny of material related to the CPC

29 ACS, CPC, b. 4902, f. 030243 Spazapan Giuseppina; f. 030191, Spazapan Paola. 
and the diplomatic service would be especially welcome. Careful research of those files would also facilitate better understanding of the emigrants' complex life-paths.

Štoka was probably right in stating that both the Italian and the Yugoslavian diplomatic representatives felt obliged to protect the emigrants from the Julian March. Nevertheless, they both "took care" of them by reporting them to the Argentine police and by handing the authorities the lists of the most active members of Ljudski oder. ${ }^{30}$ The Yugoslav authorities thought that the state represented the emigrants' homeland and subjected anybody who dared to oppose the royal regime to tight surveillance. Including the Yugoslav aspect in the research would benefit our understanding of the emigrant community. It would also allow us to obtain a comparative insight into the functioning of extraterritorial surveillance pursued by two neighbours whose regimes were not dissimilar. Moreover, placing the case of the surveillance of emigrants from the Julian March in a broader Central European interpretive framework would allow us to examine extraterritorial control in a region where little congruence between ethno-national and politico-territorial boundaries often resulted in violent assimilationist policies carried out by nationalizing states (cf. Brubaker 1996: 113). However, ascribing the qualities of the Central European area to this particular context might preclude other understandings. An intra-Italian comparison might be more fruitful. ${ }^{31}$ Firstly, a comparison with the surveillance of emigrants of the German minority from South Tyrol could provide a better insight into the general contours of the Fascist surveillance of emigrants belonging to national minorities. Secondly, a diachronic, longue durée analysis of extraterritorial control over members of minorities would allow us to tackle the continuities and discontinuities of this system of control (cf. Fonio, Agnoletto 2013). Considering the fact that the surveillance strategies introduced by the fascist regime did not subside with the eclipse of the regime (the Italian democracy did not abolish the CPC until 1968), it would be insightful to examine this diachronic aspect as well. However, the new migratory contexts appearing in the postwar period would make such an analysis an intricate endeavour.

By showing the potentials of the comparative approach I have tried to suggest directions for a subtler understanding of the link between migrations and nation-building in a period when nationalizing states were exercising unprecedented control over the emigrant communities. Nevertheless, by addressing the fascist extraterritorial surveillance of the minorities from the Julian March and the collaboration of the Italian and Argentine authorities, I hope I have made a preliminary contribution to the examination of the fascist attitude towards minorities living abroad, an issue which still remains insufficiently researched.

30 AS 1696, Franc Štoka, »Ob 37-letnici društva Ljudski oder«.

31 For dilemmas concerning the comparative approach in studying population transfers in Istria see Ballinger 2016; for a comparison between Italian policies undertaken in the annexed territories with the ones in its colonies see Pergher 2018. 


\section{REFERENCES}

Ballinger, Pamela (2016). Remapping the Istrian Exodus: New Interpretive Frameworks. At Home but Foreigners: Population Transfers in 20th Century Istria (eds. Katja Hrobat Virloget, Catherine Gousseff, Gustavo Corni). Koper: Annales University Press.

Brubaker, Rogers (2009). Nationalism Reframed. Nationhood and the National Question in the New Europe. New York: Cambridge University Press.

Brunnbauer, Ulf (2009). Transnational Societies, Transterritorial Politics: Migrations in the (Post-) Yugoslav Region: 19th-21st century. München: R. Oldenbourg.

Brunnbauer, Ulf (2012). Emigration Policies and Nation-Building in Interwar Yugoslavia. European History Quarterly 42/4, 602-627.

Cresciani, Gianfranco (2004). Refractory Migrants: Fascist Surveillance on Italians in Australia, 1922-1943. Altreitalie 14/28, 6-47.

Dilemmi, Andrea (2010). Si inscriva, assicurando. Polizia e sorveglianza del dissenso politico (Verona, 1894-1963). Dottorato di ricerca in Scienze storiche e antropologiche. Università degli studi di Verona.

De Luna, Giovanni (1995). Donne in oggetto: L'antifascismo nella società italiana 19221939. Torino: Bollati Boringhieri.

Dunnage, Jonathan (2008). Surveillance and Denunciation in Fascist Siena, 19271943. European History Quarterly 38/2, 244-265.

Ebner, Michael (2006). The Political Police and Denunciation during Fascism: A Review of Recent Historical Literature. Journal of Modern Italian Studies II/2, 209-226.

Ebner, Michael (2011). Ordinary Violence in Mussolini's Italy. New York: Cambridge University Press.

Finchelstein, Federico (2010). Transatlantic Fascism: Ideology, Violence, and the Sacred in Argentina and Italy, 1919-1945. Durham: Duke University Press.

Fonio, Chiara (2011). Surveillance under Mussolini's regime. Surveillance \& Society 9/1-2, 80-92.

Fonio, Chiara, Agnoletto, Stefano (2013). Surveillance, Repression and the Welfare State: Aspects of Continuity and Discontinuity in post-Fascist Italy. Surveillance \& Society $11 / 1-2,74-86$.

Franzina, Emilio (1983). L'emigrazione schedata: Lavoratori sovversivi all'estero e meccanismi di controllo poliziesco tra fine secolo e fascismo. Gli italiani fuori d'Italia: Gli emigranti italiani nei paesi d'adozione 1880-1940 (ed. Bruno Bezza). Milano: Franco Angeli, 773-829.

Franzinelli, Mimmo (1999). Tentacoli dell'Ovra: Agenti collaboratori e vittime della polizia politica fascista. Torino: Bollati Beringhieri.

Gabaccia, Donna (2000). Italy's Many Diasporas. London: UCL Press.

Genorio, Rado (1988). Slovenci v delavskem gibanju Argentine v obdobju med obema vojnama. Migracijske teme 4/1-2, 187-193. 
Ghirardo, Diane Yvonne (1996). Citta Fascista: Surveillance and Spectacle. Journal of Contemporary History 31/2, 347-372.

Hametz, Maura (2005). Making Trieste Italian, 1918-1954. Woodbridge: Boydell Press. Horowitz, Joel (2008). Argentina's Radical Party and Popular Mobilization, 1916-1930. University Park: Pennsylvania University Press.

lacovetta, Franca, Ventresca, Robert (1996). Italian Radicals in Canada: A Note on Sources in Italy. Labour/Le Travail 37, 205-220.

Kacin, Ivan (1937). Moje ječe (My Prisons). Slovenski izseljenski koledar za Južno Ameriko za leto 1937. Buenos Aires: Slovensko prosvetno društvo, 123-128.

Kacin Wohinz, Milica (1990). Raznarodovanje primorskih Slovencev - dejavnik za izseljevanje. Kulturno ustvarjanje Slovencev v Južni Ameriki (ur. Irene Mislej). Ljubljana: Znanstveni inštitut Filozofske fakultete Univerze v Ljubljani, 23-33.

Kacin Wohinz, Milica, Verginella, Marta (2008). Primorski upor fašizmu 1920-1941. Ljubljana: Društvo Slovenska matica.

Kalc, Aleksej (1996). L'emigrazione slovena e croata dalla Venezia Giulia ed il suo ruolo politico. Annals for Istrian and Mediterreanean Studies 6/8, 23-61.

Kalc, Aleksej (2016). Antifascisti sloveni della Venezia Giulia in Argentina tra le due guerre. Storia contemporanea in Friuli 45/46, 31-55.

Kalc, Aleksej, Milharčič Hladnik, Mirjam (2015). Prvi tržaški proces in Slovenci v ZDA. Annales: Series Historia et Sociologia 25/4, 925-936.

Kalmanowiecki, Laura (2000). Origins and Applications of Political Policing in Argentina. Latin American Perspectives 27/2, 36-56.

Korzeniewicz, Roberto P. (1993). The Labor Politics of Radicalism: The Santa Fe Crisis of 1928. The Hispanic American Historical Review 73/1, 1-32.

Kurinčič, Franc (1981). Na tej in na oni strani oceana. Ljubljana: Borec.

Lewis, Colin M. (1992). Economic Restructuring and Labour Scarcity: Labour in the 1920s. Essays in Argentine Labour History 1870-1930 (ed. Jeremy Adelman). London: Palgrave Macmillan, 177-199.

Luiàn Leiva, Maria (1983). Il movimento antifascista italiano in Argentina (1922-1945). Gli italiani fuori d'Italia: Gli emigranti italiani nei paesi d'adozione 1880-1940 (ed. Bruno Bezza). Milano: Franco Angeli, 549-580.

Mislej, Irene (1996). Primorska slovenska skupnost v Južni Ameriki: Pregled antifašističnega tiska 1929-1943. Zgodovinski časopis 50/1, 95-116.

Oved, laacov (1976). El trasfondo histórico de la ley 4.144, de Residencia. Desarrollo Económico 16/61, 123-150.

Patat, Luciano (1989). Giuseppe Tuntar. Udine: Instituto Friulano per la storia del movimento di liberazione.

Pergher, Roberta (2018). Mussolini's Nation-Empire: Sovereignity and Settlement in Italy's Borderlands, 1922-1943. Cambridge: Cambridge University Press.

Pretelli, Matteo (2010). Il fascismo e gli italiani all'estero. Bologna: CLUEB. 
Rahten, Andrej (2009). Izidor Cankar: Diplomat dveh Jugoslavij. Mengeš: Center za evropsko prihodnost; Ljubljana: Znanstvenoraziskovalni center Slovenske akademije znanosti in umetnosti.

Serio, Mario (1985). Esperienze in via di realizzazione presso l'archivio centrale dello stato: Il Casellario politico centrale. Informatica e archivi: Atti del convegno, Torino 17.-19. January 1985.

Sjekloča, Marko (2004). Čez morje v pozabo: Argentinci slovenskih korenin in rezultati argentinske asimilacijske politike. Celje: Fit media.

Skrbiš, Zlatko (1999). Long-Distance Nationalism: Diasporas, Homelands and Identities. Ashgate Publishing: Brookfield.

Ščurk, Mirko, Štoka, Franc (1973). 40 let Delavskega kulturnega društva »Ljudski oder« v Buneos Airesu. Slovenski izseljenski koledar 1/20, 198-207.

Tosatti, Giovanna (1992). La banca del Casellario politico centrale presso l'Archivio Centrale dello Stato. Archivi \& Computer 2/92, 134-144.

Verginella, Marta (2016). Dokončni boj med severnojadranskimi rasami v iredentističnem in fašističnem diskurzu. Acta Histriae 24/4, 705-720.

Vinci, Anna Maria (2011). Sentinelle della patria: Il fascismo al confine orientale: 19181941. Rim, Bari: Laterza.

\section{SOURCES}

Arhiv Slovenije (AS), Zbirka izseljenci v Južni Ameriki (zapuščina Franca Štoke), AS 1696.

Arhiv Slovenije (AS), fond Kraljeva kvestura v Gorici, Poročila o komunističnih dejavnostih, 1927-1940, AS 1829/362, technical unit 15.

Archivio Centrale dello Stato, Roma (ACS), Casellario Politico Centrale (SPC).:

Stoka Francesco, b. 4958, fasc. 012685;

Tuntar Giuseppe, b. 5240, fasc. 026121;

Licen Leopoldo, b. 2784;

Licen Federico, b. 2784;

Zaccaria Leopoldo, b. 5486, fasc. 116413;

Spazapan Giuseppina and Paola, b. 4902, fasc. 030243 and 030191.

Odsek za zgodovino in etnografijo pri Narodni in študijski knjižnici Trst, fond Izseljenstvo (Department of History and Ethnography at the National and Study Library in Trieste, Emigration Collection). 


\section{POVZETEK}

\section{NADZOR IN PREGANJANJE SLOVENSKIH ANTIFAŠISTOV V ARGENTINI: ZAROTNIŠKO DELOVANJE OBLASTI PRI SPOPADANJU Z »NEZAŽELENIMI/«PRISELJENCI \\ Miha ZOBEC}

Italijanska strategija nacionalne bonifikacije oz. čiščenja slovenskega in hrvaškega prebivalstva ter njegove nadomestitve $z$ italijanskim je $v$ Julijski krajini povzročila množično emigracijo »drugorodnega« prebivalstva. Izseljence iz te dežele je, ne glede na politično usmerjenost, povezoval antifašistični boj. Zaradi javnega obsojanja fašistične politike v Julijski krajini so italijanske oblasti budno spremljale njihova gibanja celo v oddaljeni Argentini, ki je zanje postala glavna čezoceanska država priselitve. Medtem ko je Italija nadzorovala kakršnokoli nasprotovanje politiki fašističnega režima, je Argentino zlasti skrbela dejavnost levičarskih izseljencev, ki so se vključevali v argentinsko delavsko gibanje in $v$ tamkajšnjo komunistično stranko. Preganjanje levičarskih aktivistov se je še zlasti zaostrilo po puču generala Uriburuja, ki je v Argentini uvedel vojaško diktaturo. Tudi po koncu vojaškega režima se policijsko preganjanje ni prenehalo, temveč se je še poglobilo. Argentinske oblasti so fašistični Italiji v tem času posredovale kartoteke zaprtih aktivistov, te pa so sprožile postopke za nadaljnje preiskave političnih prestopnikov. Dosjeji, ki jih je zbral fašistični režim, kažejo, da so bili med tistimi, ki so jih nadzorovali, tudi taki, ki niso bili posebej angažirani. Avtor v članku poudarja, da se je zunajteritorialni nadzor Italije nad izseljenci okrepil v času, ko je bila represija nad manjšino v Julijski krajini najbolj ostra. 